\title{
DNA CONTENT OF COLCHICINE-INDUCED ENDOPOLYPLOID NUCLEI IN VICIA FABA L.
}

\author{
M. D. BENNETT and A. J. JELLINGS \\ Plant Breeding Institute, Moris Lone, Trumpington, Cambridge
}

Received 10.iv.75

\begin{abstract}
SUMmary
The relationship between ploidy level and nuclear DNA content was investigated by Feulgen microdensitometry in colchicine induced polyploid root-tip meristem cells of three Vicia species. Nuclear DNA content is expected to increase proportionately with the increase in ploidy, assuming DNA constancy. Our results showed that:

(i) Absorption readings were significantly lower than expected for cells of higher ploidy levels.

(ii) The deviation of the absorption readings obtained below those expected increased progressively with ploidy level.

(iii) These trends occurred in absorption estimates of single metacentric chromosomes at metaphase in $V$. faba, metaphase nuclei in $V$. faba, and prophase nuclei in all three Vicia species.

(iv) Loss of chromosomal DNA, as evidenced by a large and progressive increase in the frequency of occurrence of micronuclei in cells at higher ploidy level, was partly responsible for cell absorption estimates below expectation.

(v) Variation in the density and in the absorbance of nuclear DNA may also have been a cause of absorption estimates below expectation.
\end{abstract}

In our opinion, apart from the loss of chromosomal DNA to form micronuclei, it is unlikely that any real decrease in DNA content per genome occurred in cells at higher ploidy levels.

\section{INTRODUGTION}

According to the concept of DNA constancy, the nuclear DNA content is constant for a given set of chromosomes within a species. This concept, first proposed by Boivin et al. (1948), is supported by studies using both plant (Swift, 1950) and animal (Bachmann and Cowden, 1965) species and is widely accepted as a valid generalisation (Vendrely, 1955; Kraemer et al. 1972), although a few exceptions to the rule have been found, for instance, in the genotrophs of Linum (for a review see Durrant, 1971) and between tissues within certain insect species (Fox, 1969, 1970).

The relationship between nuclear DNA content and ploidy level has been investigated first in intraspecific comparisons of diploid and polyploid nuclei within or between different tissues; and second, in interspecific comparisons using corresponding nuclei in diploid species and their known or supposed polyploid relatives. In both types of comparison, if DNA constancy is obeyed, then an increase in ploidy level should result in a directly proportional increase in nuclear DNA content. Similarly, it would be expected that the DNA content of allopolyploids should equal the sum of the DNA amounts of their constituent diploid genomes.

These expectations have been fulfilled in many comparisons of diploid 
species with autopolyploid and/or allopolyploid species (Becak et al., 1967; Southern, 1967; Grant, 1969; Nishikawa, 1970; Pegington and Rees, 1970; Yang and Dodson, 1970; Bennett and Smith, 1971 ; Bullen and Rees, 1972; Narayan and Rees, 1974). However, a few instances have been noted, in which the observed DNA amount of a polyploid species differed significantly from expectation (Christensen, 1966; Becak et al., 1967; Southern, 1967; Grant, 1969). It is clear that changes in the DNA contents of diploid genomes in polyploid species are not a consequence of polyploidy itself, since the DNA contents of many established polyploids have apparently not changed since they were first formed. In view of the wide ranges of nuclear DNA contents found in several comparisons of closely related diploid species (Jones and Rees, 1968; Chooi, 1971; Bennett, 1972), it is perhaps surprising that the majority of polyploid species studied have the expected DNA amounts. The nuclear DNA contents of both diploid parent and derived polyploid species may change during evolution subsequent to the time when a polyploid species was synthesised. Thus, differences between the nuclear DNA contents of established polyploid species and those expected values derived from related diploid species presumably reflect evolutionary changes of positive or neutral adaptive significance. Such differences should not, therefore, be cited as exceptions to the rule of DNA constancy.

Besides comparing naturally occurring diploid and polyploid cells, the relationship between nuclear DNA content and ploidy level may be studied by using induced polyploid nuclei. Recently, Deka and Sen (1973) induced $4 \mathrm{n}, 8 \mathrm{n}$ and $16 \mathrm{n}$ nuclei in Vicia faba root-tip meristem cells with colchicine. Using Feulgen microdensitometry they estimated the DNA contents of untreated diploid cells and colchicine-induced polyploid cells at metaphase. They stated that, while the overall karyological integrity of the chromosomes and their numbers remained apparently normal, a progressive decline in DNA content per genome took place at successively higher ploidy levels.

Since the results of Deka and Sen (loc. cit.) are contrary to the generally obeyed rule of DNA constancy we decided to conduct similar experiments using Vicia faba and two other diploid Vicia species whose DNA amounts differed markedly from that of $V$. faba.

\section{Materials AND methods}

Seeds of Vicia faba, V. sativa $(2 n=2 x=12)$ and $V$. narbonensis $(2 n=$ $2 x=14$ ) were soaked in distilled water for about 6 hours and then germinated in vermiculite for 4-7 days. Afterwards main roots 2-4 cm long were immersed in constantly aerated, 0.005 per cent $(\mathrm{w} / \mathrm{v})$ colchicine solution in light-tight plastic bowls at $20 \pm 1{ }^{\circ} \mathrm{C}$ for up to 5 days. Concurrent with the start of colchicine treatment untreated roots (controls) were fixed in $1: 3$ acetic alcohol. Twenty treated roots of each species were fixed in $1: 3$ acetic alcohol at daily intervals after the start of colchicine treatment for 5 days.

The colchicine treatment used induced the formation of polyploid cells as described by Deka and Sen (1973). As a rule, cells of successively higher ploidy levels were found in roots fixed on successive days; however, a few $32 \mathrm{n}$ cells were found in roots fixed 3 days after the start of treatment. The highest ploidy level of cells found in $V$. faba and $V$. sativa was $32 \mathrm{n}$ and $64 \mathrm{n}$ 
respectively. In $V$. narbonensis no cell was found with a ploidy level higher than $16 \mathrm{n}$, and nuclei having reached this ploidy level apparently always degenerated.

Fixed roots for microdensitometry were hydrolysed in $1 \mathrm{~N} \mathrm{HCl}$ at $60^{\circ} \mathrm{C}$ for 10 minutes, stained in leuco-basic fuchsin at $p \mathrm{H} 3.6$ for 2 hours, given three 10-minute washes in $\mathrm{SO}_{2}$ water, and finally washed in distilled water. Treated roots of one species, all fixed at a single sampling time, were prepared for microdensitometry in a single tube together with control roots. Root-tip squashes of control and treated roots were prepared using separate slides. The relative absorption at $565 \mathrm{~nm}$ of individual Feulgen stained nuclei, micronuclei, or single metacentric chromosomes was measured using a Vickers M86 scanning microdensitometer. Each measurement was the mean of three readings. At each sampling time and for each species, measurements were made on not less than 30 nuclei, or single chromosomes ten on each of three slides. Each slide (replicate) was prepared using a single root-tip from a different plant. Metaphase and prophase nuclei were measured in $V$. faba while only the latter were measured in $V$. sativa and $V$. narbonensis. The mean DNA contents of nuclei, micronuclei and known chromosomes were calculated in relative absorption units (r.a.u.) with respect to a diploid prophase control value for $V$. faba of $44 \cdot 0$. This value was chosen to facilitate easy comparison between the present results and those of Deka and Sen (1973) who based their results on a DNA amount for Vicia faba of 44 picograms published by Baetcke et al. (1967). It should be noted, however, that the value given by Baetcke et al. is not a $4 C$ value but is a "per cell" value. As such it only approximates to the $3 C$ amount (Bennett, 1972) unlike estimates for prophase and metaphase, which are exact $4 C$ amounts.

When comparing prophase or metaphase nuclei at different ploidy levels, care was taken to measure only cells which appeared to be complete. Below $16 \mathrm{n}$, estimates for individual nuclei fell into discrete populations corresponding to $2 n, 4 n$ and $8 n$ cells. At $16 n$ and $32 n$, however, the distinction between populations of cells was less obvious. Consequently, ranges of values for $16 \mathrm{n}$ and $32 \mathrm{n}$ cells were chosen which, in our judgment, most closely defined the populations of cells at these ploidy levels. We accept that this may introduce error in estimating the mean r.a. of $16 \mathrm{n}$ and $32 \mathrm{n}$ cells.

In Vicia faba, the haploid chromosome set consists of five subtelocentric (st) chromosomes and one metacentric $(m)$ chromosome, about twice as large as each of the former. It was decided to study a single known chromosome in cells of different ploidy levels and the $m$ chromosome was chosen because of its distinctive size and appearance. Using the microdensitometer both absorption and area readings were made on single $m$ chromosomes at metaphase in diploid control and in colchicine treated cells with ploidy levels from $2 \mathrm{n}$ to $32 \mathrm{n}$.

Absorption measurements of micronuclei and single chromatids were made using colchicine treated roots fixed after 3,4 and 5 days of treatment. Random samples of 50 micronuclei and 50 single chromatids were measured at each sampling time. Care was taken not to make measurements in degenerating cells. The number of micronuclei per cell, and the percentage of cells containing micronuclei was estimated in random samples of 1000 interphase cells in squashes of root-tip meristems fixed after successive days of colchicine treatment. It should be noted that the method 
greatly underestimated the absolute number of micronuclei produced for several reasons. First, micronuclei lying above or below an interphase nucleus were usually undetected. Second, many micronuclei were degraded soon after their formation and hence were not scored. Third, no estimates were made in obviously degenerating cells, yet such cells frequently contained very high numbers of micronuclei.

\section{TABLE 1}

The expected and observed mean absorption per nucleus for prophase and metaphase nuclei at different ploidy levels in Vicia faba (data in r.a.u.)

\begin{tabular}{|c|c|c|c|c|c|c|c|}
\hline \multirow[b]{2}{*}{$\begin{array}{l}\text { Ploidy } \\
\text { level }\end{array}$} & \multirow[b]{2}{*}{$\begin{array}{l}\text { Expected } \\
\text { absorption } \\
\text { per nucleus }\end{array}$} & \multicolumn{3}{|c|}{ Prophase } & \multicolumn{3}{|c|}{ Metaphase } \\
\hline & & $\begin{array}{l}\text { Mean absorption } \\
\text { per nucleus } \\
\text { observed }\end{array}$ & $\begin{array}{c}\text { Percentage } \\
\text { deviation of } \\
\text { observed from } \\
\text { expected }\end{array}$ & $\mathbf{P}^{*}$ & $\begin{array}{c}\text { Mean absorption } \\
\text { per nucleus } \\
\text { observed }\end{array}$ & $\begin{array}{c}\text { Percentage } \\
\text { deviation of } \\
\text { observed from } \\
\text { expected }\end{array}$ & $P^{*}$ \\
\hline 2n control & $44 \cdot 00$ & $44.00 \pm 1.51$ & 一 & - & - & - & - \\
\hline $2 n$ treated & $44 \cdot 00$ & $43.27 \pm 1.09$ & -1.66 & n.s. & $37 \cdot 08 \pm 3 \cdot 25$ & $-15 \cdot 73$ & $* * *$ \\
\hline $4 n$ treated & $88 \cdot 00$ & $85 \cdot 50 \pm 6 \cdot 21$ & $-2 \cdot 84$ & n.s. & $70 \cdot 81 \pm 6 \cdot 17$ & -19.53 & $* * *$ \\
\hline 8n treated & $176 \cdot 00$ & $158.98 \pm 24.52$ & $-9 \cdot 67$ & $*$ & $140 \cdot 45 \pm 23 \cdot 03$ & $-20 \cdot 20$ & $* * *$ \\
\hline 16n treated & $352 \cdot 00$ & $282 \cdot 81 \pm 36 \cdot 69$ & $-19 \cdot 66$ & $* * *$ & $269 \cdot 93 \pm 50 \cdot 69$ & $-23 \cdot 32$ & $* * *$ \\
\hline $32 n$ treated & $704 \cdot 00$ & $531 \cdot 02 \pm 74 \cdot 20$ & -24.57 & $* * *$ & $500 \cdot 36 \pm 76 \cdot 10$ & -28.93 & $* * *$ \\
\hline
\end{tabular}

N.B.-Probability in tables 1,3 and 4 was calculated using mean absorption readings and not using the percentage deviation of observed readings from those expected.

TABLE 2

The mean absorption per 4C nucleus at early, mid and late prophase and at pro-metaphase

\begin{tabular}{lcc}
\multicolumn{1}{c}{ Mean absorption } & \\
Stage & $\begin{array}{c}\text { per nucleus } \\
\text { (arbitrary units) }\end{array}$ & P \\
Early prophase & $18.53 \pm 0.86$ & - \\
Mid prophase & $18.26 \pm 0.87$ & n.s. \\
Late prophase & $18.06 \pm 0.89$ & $*$ \\
Pro-metaphase & $16.75 \pm 0.70$ & $* * *$
\end{tabular}

\section{Results}

(i) Relative absorption in $4 \mathrm{C}$ cells of $\mathrm{V}$. faba

Table 1 presents estimates of the mean relative absorption per cell for prophase and metaphase stages in cells of different ploidy levels. At both mitotic stages the absorption estimates obtained were significantly lower $(\mathrm{P}<0.001$ per cent $)$ than expected for cells at higher ploidy levels. Moreover, the higher the ploidy level of the cell, the greater was the deviation of the observed results from those expected.

Metaphase cells gave significantly lower absorption readings than prophase cells at each of the five ploidy levels studied (table 1). This difference is not due to real changes in nuclear DNA content since both prophase and metaphase cells contain the $4 C$ DNA amount, but is probably 
caused by changes in DNA density which occur during chromosome contraction at early mitosis. A comparison of diploid control nuclei at early, mid and late prophase and at pro-metaphase (i.e. nuclei with a constant $4 C^{\circ}$ DNA amount) gave results which support this hypothesis (table 2). There was a steady fall in mean absorption per nucleus as chromosome contraction (and hence, DNA density) increased.

\section{(ii) Relative absorption in three Vicia species}

Estimates of the mean absorption per diploid genome in cells of different ploidy levels in $V$. sativa, $V$. narbonensis and $V$. faba at prophase (table 3 ) were significantly lower in cells of higher ploidy level than in control diploid cells. Moreover, in each species the difference between estimates for control and treated cells increased with increasing ploidy level.

TABle 3

The mean absorption per nucleus and per diploid genome in diploid control nuclei and colchicine trealed nuclei at prophase in cells of different ploidy levels from three Vicia species (data in r.a.u.)

\begin{tabular}{|c|c|c|c|c|c|}
\hline Species & Ploidy level & $\begin{array}{l}\text { Mean } \\
\text { absorption } \\
\text { per nucleus }\end{array}$ & $\begin{array}{c}\text { Mean } \\
\text { absorption } \\
\text { per genome }\end{array}$ & $\begin{array}{l}\text { Percentage decrease } \\
\text { relative to diploid } \\
\text { control value }\end{array}$ & $\mathbf{P}$ \\
\hline V. sativa & $\begin{array}{l}2 n \text { control } \\
4 n \text { treated } \\
8 \mathrm{n} \text { treated } \\
16 n \text { treated } \\
32 n \text { treated }\end{array}$ & $\begin{array}{r}8.20 \pm 1.28 \\
16.00 \pm 1.71 \\
30.96 \pm 5.13 \\
56.03 \pm 6.64 \\
111.78 \pm 14.76\end{array}$ & $\begin{array}{l}8 \cdot 20 \\
8 \cdot 00 \\
7 \cdot 74 \\
7 \cdot 00 \\
6 \cdot 99\end{array}$ & $\begin{array}{r}- \\
-2 \cdot 44 \\
-5 \cdot 61 \\
-14 \cdot 63 \\
-14 \cdot 76\end{array}$ & $\begin{array}{l}- \\
\text { n.s. } \\
\text { n.s. } \\
* * * \\
* * *\end{array}$ \\
\hline$V$. narbonensis & $\begin{array}{l}2 n \text { control } \\
4 n \text { treated } \\
8 n \text { treated } \\
16 n \text { treated }\end{array}$ & $\begin{array}{r}25 \cdot 00 \pm 1 \cdot 35 \\
47 \cdot 69 \pm 5 \cdot 16 \\
86 \cdot 36 \pm 6 \cdot 06 \\
166 \cdot 57 \pm 11 \cdot 92\end{array}$ & $\begin{array}{l}25 \cdot 00 \\
23 \cdot 85 \\
21 \cdot 59 \\
20 \cdot 82\end{array}$ & $\begin{array}{r}- \\
-4 \cdot 60 \\
-13 \cdot 64 \\
-16 \cdot 72\end{array}$ & $\begin{array}{l}- \\
\text { n.s. } \\
* * * \\
* * *\end{array}$ \\
\hline V. faba & $\begin{array}{l}2 \mathrm{n} \text { control } \\
2 \mathrm{n} \text { treated } \\
4 \mathrm{n} \text { treated } \\
8 \mathrm{n} \text { treated } \\
16 \mathrm{n} \text { treated } \\
32 \mathrm{n} \text { treated }\end{array}$ & $\begin{array}{r}44.00 \pm 1.51 \\
43.27 \pm 1.09 \\
85.50 \pm 6.21 \\
158.98 \pm 24.52 \\
282.81 \pm 36.69 \\
531.02 \pm 74.20\end{array}$ & $\begin{array}{l}- \\
43 \cdot 27 \\
42 \cdot 75 \\
39 \cdot 75 \\
35 \cdot 35 \\
33 \cdot 19\end{array}$ & $\begin{array}{r}-1.66 \\
-2.84 \\
-9.67 \\
-19.66 \\
-24.57\end{array}$ & $\begin{array}{l}\text { - } \\
\text { n.s. } \\
\text { n.s. } \\
* \\
* * * \\
* * *\end{array}$ \\
\hline
\end{tabular}

(iii) Measurement of the $\mathrm{m}$ chromosome in $\mathrm{V}$. faba

Table 4 gives the mean absorption per $m$ chromosome in diploid control cells and in colchicine treated cells of different ploidy levels at metaphase. The results show a progressive and significant $(\mathrm{P}<0.001$ per cent $)$ fall in this character as ploidy level increased. Table 4 gives results showing a similar trend for $m$ chromosome area. For instance, the mean absorption and the mean area per $m$ chromosome was respectively 16.8 and 20.1 per cent lower in $32 \mathrm{n}$ cells than in diploid control cells. Analysis showed a significant relationship $(\mathrm{P}<0.05$ per cent : $r=0.84)$ between mean absorption and mean area per $m$ chromosome in cells of different ploidy levels. 


\section{TABLE 4}

The mean absorption and the mean area at metaphase per single metacentric chromosome in untreated diploid cells (control) and colchicine treated cells at different ploidy levels in $\mathrm{V}$. faba

\begin{tabular}{|c|c|c|c|c|c|c|}
\hline $\begin{array}{l}\text { Ploidy } \\
\text { level }\end{array}$ & $\begin{array}{l}\text { Mean absorption } \\
\text { per single } m \\
\text { chromosome } \\
\text { (r.a.u.) }\end{array}$ & $\begin{array}{l}\text { Percentage decrease } \\
\text { relative to diploid } \\
\text { control value }\end{array}$ & $\mathbf{P}$ & $\begin{array}{l}\text { Mean area } \\
\text { per single } m \\
\text { chromosome } \\
\text { (a.u.) }\end{array}$ & $\begin{array}{l}\text { Percentage decrease } \\
\text { relative to diploid } \\
\text { control value }\end{array}$ & $P$ \\
\hline $2 n$ control & $6 \cdot 27 \pm 0.53$ & - & - & $164 \pm 23$ & - & - \\
\hline $2 n$ treated & $6 \cdot 14 \pm 0 \cdot 41$ & $2 \cdot 07$ & n.s. & $159 \pm 21$ & $3 \cdot 05$ & s.s. \\
\hline 4n treated & $6.05 \pm 0.66$ & 3.51 & n.s. & $148 \pm 18$ & $9 \cdot 76$ & $* *$ \\
\hline $8 \mathrm{n}$ treated & $5 \cdot 66 \pm 0 \cdot 68$ & $9 \cdot 73$ & $* * *$ & $135 \pm 20$ & $17 \cdot 68$ & $* * *$ \\
\hline $16 n$ treated & $5.85 \pm 0.67$ & $6 \cdot 70$ & * & $131 \pm 17$ & $20 \cdot 12$ & $* * *$ \\
\hline $32 n$ treated & $5 \cdot 22 \pm 0 \cdot 48$ & $16 \cdot 75$ & *** & $131 \pm 16$ & $20 \cdot 12$ & $* * *$ \\
\hline
\end{tabular}

\section{TABLE 5}

The percentage of cells containing micronuclei, and the mean number of micronuclei per cell containing micronuclei, in Vicia faba root-tip meristem cells treated with colchicine for up to 5 days

$\begin{array}{ccc}\begin{array}{c}\text { Days of treatment } \\ \text { with } 0 \cdot 005 \%\end{array} & \begin{array}{c}\text { Percentage of } \\ \text { cells with } \\ \text { micronuclei }\end{array} & \begin{array}{c}\text { Mean number of } \\ \text { micronuclei per cell } \\ \text { containing micronuclei }\end{array} \\ 0 & 0 \cdot 111 & 1 \cdot 00 \\ 1 & 0.740 & 1 \cdot 00 \\ 2 & 1.444 & 1.33 \\ 3 & 4.741 & 1 \cdot 40 \\ 4 & 12.037 & 2 \cdot 25 \\ 5 & 17.667 & 3 \cdot 13\end{array}$

\section{TABLE 6}

The mean number of micronuclei per cell in root-tip meristem cells of three Vicia species treated with 0.005 per cent colchicine for up to 5 days

\begin{tabular}{|c|c|c|c|}
\hline \multirow{2}{*}{$\begin{array}{l}\text { Days of treatment } \\
\text { with } 0.005 \% \\
\text { colchicine }\end{array}$} & \multicolumn{3}{|c|}{ Species } \\
\hline & V. sativa & V. narbonensis & V. $f a b a$ \\
\hline 0 & 0.001 & 0.001 & 0.001 \\
\hline 1 & - & 0.075 & 0.007 \\
\hline 2 & 0.074 & $0 \cdot 233$ & $0 \cdot 019$ \\
\hline 3 & 0.260 & 0.149 & $0 \cdot 070$ \\
\hline 4 & 0.340 & - & $0 \cdot 272$ \\
\hline 5 & 0.336 & $1 \cdot 187$ & 0.539 \\
\hline
\end{tabular}

\section{TABLE 7}

The mean absorption per micronucleus or per chromatid in a random sample of micronuclei and chromatids (150 of each) from roots fixed at $3-5$ days after the start of colchicine treatment

Class of micronucleus or chromatid

Class I (r.a. $<1 \cdot 75)$

Class II (r.a. > 1.75)

Chromatids

$\begin{array}{cc}\text { Micronuclei } & \mathrm{P} \\ 1 \cdot 08 \pm 0 \cdot 22 & * * * \\ 2 \cdot 36 \pm 0 \cdot 54 & * \\ 1 \cdot 25 \pm 0 \cdot 62 & * * *\end{array}$

Total population

$1 \cdot 20 \pm 0 \cdot 26$

$2 \cdot 65 \pm 0 \cdot 43$

$1 \cdot 49 \pm 0.74$

$1 \cdot 25 \pm 0.62$ 


\section{(iv) Micronuclei}

The frequency of occurrence of micronuclei in control roots was almost zero in all three Vicia species, but reached high levels after 5 days of colchicine treatment (tables 5 and 6). Both the percentage of cells containing micronuclei, and the mean number of micronuclei per cell, increased steadily in
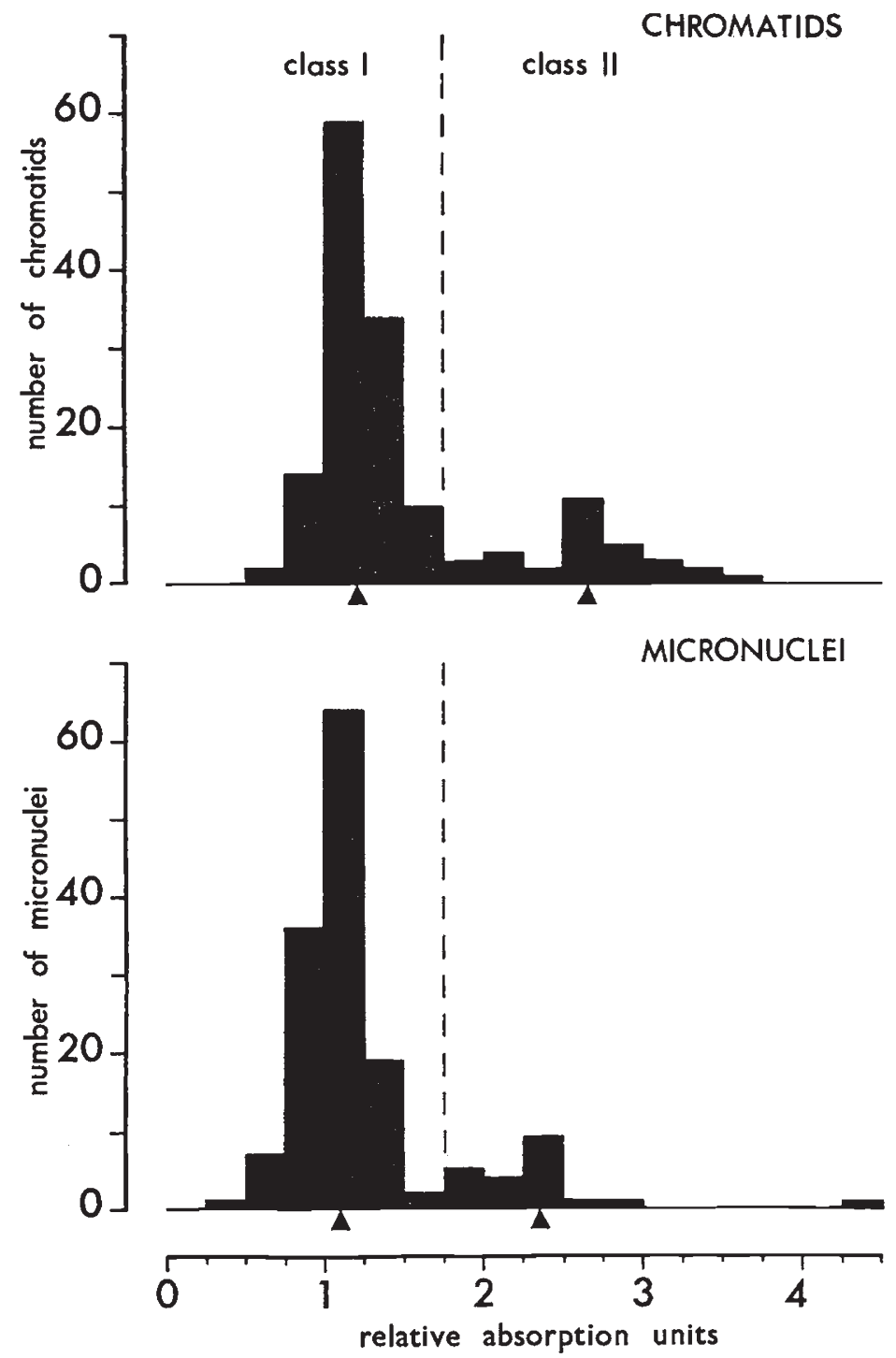

Frg. 1.-The DNA content (in relative absorption units) of random samples of 150 chromatids and micronuclei. Arrows indicate the means for Class I and Class II chromatids and micronuclei (see Section 3.iv).

treated $V$. faba roots sampled on successive days (table 5). For instance, in $V$. faba roots sampled after the 5 th day of treatment about 17.7 per cent of root-tip cells contained micronuclei and each cell contained an average of more than 3 micronuclei.

Figure 1 shows the distribution frequency of micronuclei and chromatids 
with different relative absorption amounts. The histogram for single chromatids shows a bimodal distribution as expected; the two peaks presumably correspond to chromatids from $s t$ and $m$ chromosomes. To facilitate comparison between the DNA contents of single chromatids and micronuclei, the population of chromatids was divided into two classes, those with r.a. of less than 1.75 (Class I) and those with r.a. of more than 1.75 (Class II). The mean r.a. for Class I chromatids should approximate to the mean for $s t$ chromosomes, while the mean for Class II chromatids to that for $m$ chromosomes. Comparison of the histograms for chromatids and micronuclei shows that they have very similar distribution patterns, furthermore, the mean r.a. for Class I and II chromatids is close to that for Class I and II micronuclei (table 7). The mean r.a. for micronuclei is significantly lower than for chromatids for both Class I and Class II. Nevertheless, it is not unreasonable to suggest that at least the majority of micronuclei were formed from single chromatids. The significant fall in mean r.a. for micronuclei compared with chromatids may be due either to increased DNA density in the former, or, to chromosome breakage so that some micronuclei are formed from chromosome fragments.

\section{Discussion}

Our results agree with those of Deka and Sen (1973) in showing a progressive decrease in r.a. per genome with increasing ploidy level in Vicia faba nuclei at metaphase. Moreover, measurements of the $m$ chromosome at metaphase in $V$. faba showed a similar pattern of decreasing r.a. with increasing ploidy level to that found for whole nuclei at metaphase. The present results also show a similar trend with increasing ploidy level for nuclei at prophase in three Vicia species. Thus, the factor(s) responsible for the decrease in r.a. per genome noted at metaphase in Vicia faba at higher ploidy (Deka and Sen, 1973) is shown to affect each individual chromosome, and to act at stages of mitosis besides metaphase, and in other species besides $V$. faba. It is necessary, therefore, to question the nature of the cause of such variation.

The present results, showing a progressive decrease in r.a. per genome with increasing ploidy level are open to two main interpretations. First, they may indicate a real decrease in DNA content per nucleus below that expected assuming DNA constancy. Second, they may indicate an apparent loss of DNA per genome and have a physical basis associated either with variation in the nature of the nuclei being measured (for example, their density), or with errors inherent in the techniques used to measure them.

A real decrease in DNA amount per genome could have one of three main causes:

(i) aneuploidy,

(ii) chromosome breakage with subsequent loss of acentric fragments,

(iii) the loss of, or the reduced replication of repeated base sequences (Cullis, 1973; Maher and Fox, 1973).

Loss of DNA due to aneuploidy or chromosome breakage should be readily detected in cytological examination of treated tissues. Deka and Sen (1973) stated that the loss of DNA in colchicine induced polyploid cells was not due either to aneuploidy or to chromosome breakage. 
In the present work, a real loss of DNA from the nucleus was partly responsible for the decreased mean r.a. per nucleus at higher ploidy levels in $V . f a b a$. The percentage of cells containing micronuclei, and the mean number of micronuclei per cell, increased dramatically in colchicine treated roots during the 5 days of treatment (tables 5 and 6). It is impossible in the present work to estimate accurately the mean loss of chromosomal DNA due to micronucleus formation in cells of known different ploidy, because, as described in the methods, the number of micronuclei was greatly underestimated by the scoring method used.

Both aneuploidy and chromosome breakage can result in the formation of micronuclei. A comparison of the r.a. of random samples of chromatids and micronuclei (fig. 1 and table 7) showed a very similar bimodal distribution for both, but the mean r.a. per micronucleus was significantly lower than the mean r.a. per chromatid. Nevertheless, the DNA contents of most micronuclei were equivalent to the amounts expected if micronuclei were produced from single whole chromatids lost at c-mitosis. Consequently, it seems reasonable to suggest that the majority of micronuclei were formed as a result of aneuploidy.

Some micronuclei may have been formed after chromosome breakage. Evidence to support this notion was found in cytological investigation of metaphase cells which occasionally showed clear evidence of chromosome breakage. Chromosome breakage in Vicia faba usually results in the production of very large acentric fragments (Levan and Lofty, 1950; Darlington and McLeish, 1951; Kihlman and Levan, 1951) whose DNA contents would be similar to, but slightly less than that of $s t$ chromatids. Colchicine treatment itself does not cause chromosome breakage (Davidson, 1957). However, oxygen deficiency has a pronounced effect in causing chromosome breakage (Michaelis and Rieger, 1958). Levan and Lotfy (1950) found cells frequently had one or two large fragments and about 10 per cent of cells displayed disturbed mitosis in roots from $V$. faba seeds presoaked for 24 hours before germination. They noted mitotic disturbance in 13.1 per cent of cells treated with $150 \times 10^{-6} \mathrm{~mol} / \mathrm{L}$ colchicine, after presoaking (a concentration very close to that used by Deka and Sen and in the present work). They showed that mitotic disturbance in both control and colchicine treated roots was caused by anaerobis during presoaking. The cause of chromosome breakage in the present work is unknown, but it should be noted that it occurred after a very short period of presoaking (about 6 hours) and despite constant aeration of the culture solution. Deka and Sen (1973) did not state whether their seeds were presoaked or whether their culture solution was aerated.

Although loss of chromosomal DNA was a significant factor responsible for part of the decrease in absorption below that expected for cells at higher ploidy, nevertheless, it was not the only major cause. The mean absorption of a single $m$ chromosome showed a 16 per cent drop in polyploid cells (table 4 ) below the control value in the absence of any obvious change in the structure of the chromosome. This fall in absorption readings, is not explained by loss of nuclear DNA accompanying either aneuploidy or chromosome breakage.

A decrease in r.a. of this type may be due to a real reduction in chromosomal DNA content. However, estimates of nuclear DNA content made by microdensitometry are subject to several well known errors. 
Consequently considerable caution is required before concluding that a decrease in r.a. per chromosome or per genome indicates a real, rather than an apparent, loss of DNA.

An apparent fall in DNA content may have a physical basis associated with the technique used to measure absorption. Errors have been recognised which are inherent to the optical system used for microdensitometry, for example, that caused by glare. The amount of glare (and hence the size of the error involved) is closely related to the size of the specimen free field illuminated. This error increases sharply with increasing absorbance of chromatin (and hence with increased chromosome contraction (Goldstein, 1970). Clearly, therefore, the errors involved in reading well-spread metaphase plates are much greater than those involved in measuring prophase nuclei, since both the illuminated specimen free area and the absorbance of chromatin is high at metaphase compared with prophase. Goldstein (1970) stated that, " apparent differences of the amount of dye taken up by nuclei of different sizes, stained by the Feulgen method, which have been reported by various workers and attributed to differences in DNA content, are of an order of magnitude which could be due to the presence of glare". We strongly suggest that errors of these types may be partly or totally responsible for the apparent decrease in DNA content at higher ploidy levels in $V$. faba noted by Deka and Sen (1973), and in the present work.

Apart from errors of the type mentioned above, apparent variation in DNA content can be caused by variation in the nature of the nuclei being measured. For example, several workers have noted that the accuracy of DNA measurements by microdensitometry is markedly influenced by nuclear DNA density. To be specific, DNA amount tends to be underestimated as the DNA density increases (Mittwoch, 1969; Narayan and Rees, 1974; Verma and Rees, 1974). Evidence showing that this occurred in Vicia faba in the present work is given in table 2, which shows a significant fall in absorption of nuclei with a constant $4 C$ DNA amount as DNA density was increased during early mitosis.

Large natural and induced variation in the volume of untreated and colchicine treated metaphase chromosomes has been noted in several species, including V. faba (Pierce, 1937; Bennett and Rees, 1969; Bennett, 1970). In $V$. faba grown in sand for up to 38 days the mean volume per cell of c-metaphase chromosomes varied by more than two-fold. The variation in metaphase chromosome volume was not accompanied by any variation in $4 C$ nuclear DNA content and, therefore, involved large changes in the density of DNA in metaphase chromosomes (Bennett, 1970). We questioned, therefore, whether changes in c-metaphase chromosome volume (and hence in DNA density) may have contributed to the apparent decrease in DNA per genome at higher ploidy levels in the present work.

Table 8 presents previously unpublished results giving the total mean volume per cell of all 12 metaphase chromosomes in $V$. faba roots transferred from growing in sand to culture in constantly aerated distilled water at $20^{\circ} \mathrm{C}$ for up to 25 hours. After 25 hours in culture chromosome volume had decreased significantly, from 350 arbitrary units (a.u.) to 280 a.u. in main roots, and from 420 a.u. to $250 \mathrm{a} . \mathrm{u}$. in lateral roots. This decrease in chromosome volume occurred in diploid cells with a constant $4 C$ DNA amount, and consequently involved an increase in DNA density due to either culture treatment, or ageing. 
In the present work there was a significant and progressive decrease in the size of the $m$ chromosome with increasing colchicine treatment period (table 4). This decrease may reflect a progressive increase in DNA density with increasing time in culture, similar to that found in all the chromosomes of $V . f a b a$ from roots cultured in aerated distilled water described above. If so, then error associated with a progressive increase in the density of chromosomal DNA, due to reduced metaphase chromosome volume, may also have been a cause of the progressive decrease in absorption per genome in cells at higher ploidy.

TABLE 8

The mean total volume per cell of c-metaphase chromosomes in main root-tip meristem cells of Vicia faba cultured in aerated distilled water for up to 25 hours. Significant differences between the volumes of control and treated nuclei in each type of root are indicated

\begin{tabular}{ccc}
$\begin{array}{c}\text { Duration of culture } \\
\text { in aerated distilled } \\
\text { water (hours) }\end{array}$ & \multicolumn{2}{c}{$\begin{array}{c}\text { Chromosome volume } \\
\text { (arbitrary units) }\end{array}$} \\
0 (control) & 349.5 & 422.6 \\
5 & $395 \cdot 1$ & $439 \cdot 1$ \\
10 & $300 \cdot 5$ & 297.0 \\
15 & - & 292.0 \\
20 & 264.0 & - \\
25 & 278.0 & 288.3
\end{tabular}

N.B.-Data are the mean of 10 cells. Full details of the methods used have been given previously (Bennett, 1970).

Two lessons may be drawn from the present work. First, estimation of nuclear DNA content by microdensitometry requires careful attention to the known sources of error inherent to the material and the methods. Without undertaking further detailed studies it will not be possible to define the relative contributions of the different known, or suspected, causes of reduced relative absorption per genome in cells of higher ploidy. Second, we have shown that loss of whole chromosomes or of fragments into micronuclei accounts for at least a large part of the DNA diminution in cells of higher ploidy level. Whether there is DNA loss over and above this, as claimed by Deka and Sen (1973) must remain in some doubt. In our opinion, it is more likely that the decreased absorption per genome in polyploid cells noted by Deka and Sen (loc. cit.) and in the present work denotes an apparent, rather than a real, loss of chromosomal DNA.

\section{REFERENGES}

BACHMANN, K., AND COWDEN, R. R. 1965. Quantitative cytophotometric studies on isolated liver nuclei of the bullfrog, Rana catesbeina. Chromosoma (Berl.), 17, 22-34.

BAETCKe, K. P., SPARROW, A. H., NAUMANN, C. H., AND SCHWEMMER, s. s. 1967. The relationship of DNA content to nuclear and chromosome volumes and to radiosensitivity $\left(L_{50}\right)$. Proc. Nat. Acad. Sci. USA., 58, 533-540.

BEGAK, W., BECAK, M. L., LAVILLE, D. AND SGHREIBER, G. 1967. Further studies on polyploid amphibians (Ceratophrydidae). Chromosoma (Berl.), 23, 14-23.

BENNETT, M. D. 1970. Natural variation in nuclear characters of meristems in Vicia faba. Chromosoma (Berl.), 29, 317-335.

BENNETT, M. D. 1972. Nuclear DNA content and minimum generation time in herbaceous plants. Proc. Roy. Soc. Lond. B, 181, 109-135.

BENNETT, M. D., AND REES, H. 1969. Natural and developmental variation in chromosomes in meristematic cells. Chromosoma (Berl.), 27, 226-244. 
BenNetT, M. D., AND SMITH, J. B. 1971. The $4 C$ nuclear DNA content of several Hordeum genotypes. Can. 7. Genet. Cytol., 13, 607-611.

BOIVIN, A., VENDRELY, R., AND VENDRELY, c. 1948. L'acide desoxyribonucleique du noyau cellulaire, depositaire des caracteres hereditaires; arguments d'ordre analytique. C. $r$. hebd. Seanc. Acad. Sci. Paris, 226, 1061-1063.

BUllen, M. R., AND ReEs, H. 1972. Nuclear variation in Avena. Chromosoma (Berl.), 39, 93-100.

chоor, w. Y. 1971. Variation in nuclear DNA content in the genus Vicia. Genetics, 68, 195-211.

CHRISTENSEN, B. 1966. Cytophotometric studies on the DNA content in diploid and polyploid Enchytraeidae (Oligocheta). Chromosoma (Berl.), 18, 305-315.

cullis, C. A. 1973. DNA differences between flax genotrophs. Nature, 243, 515-516.

DARLINGTON, C. D., AND MCLEISH, J. 1951. Action of maleic hydrazide on the cell. Nature, $167,407$.

DAvidson, D. 1957. Relationship of colchicine to chromosome breakage. Nature, 180, 1059-1060.

DEKA, P. C., AND SEN, s. K. 1973. Decrease in chromosomal DNA at higher polyploid level in Vicia faba root meristems. Can. 7. Genet. Cytol., 15, 863-865.

DURRANT, A. 1971. Induction and growth of flax genotrophs. Heredity, 27, 277-298.

FOX, D. P. 1969. DNA value in somatic tissues of Dermestes (Dermestidae: Coleoptera). I. Abdominal fat body and testis wall of the adult. Chromosoma (Berl.), 28, 445-456.

Fox, D. P. 1970. A non-doubling DNA series in somatic tissues of the locusts Schistocerca gregaria (Forskål) and Locusta migratoria (Linn.). Chromosoma (Berl.), 29, 446-461.

GoldsTeIN, D. J. 1970. Aspects of scanning microdensitometry. I. Stray light (glare). 7. Microscopy, 92, 1-16.

GRANT, W. F. 1969. Decreased DNA content of Birch (Betula) chromosomes at high ploidy level as determined by cytophotometry. Chromosoma (Berl.), 26, 326-336.

JONES, R. N., AND REES, H. 1968. Nuclear DNA variation in Allium. Heredity, 23, 591-605. KIHLMAN, B., AND LEVAN, A. 1951. Localised chromosome breakage in Vicia faba. Hereditas, 37, 382-388.

KRAEMER, P. M., DEAVEN, L. L., CRISSMAN, H. A., AND VAN DILlA, M. A. 1972. DNA constancy despite variability in chromosome numbers. In Advances in Cell $\mathcal{E}^{\circ}$ Molecular Biology, pp. 46-108, ed. E. J. Dupraw. Academic Press, N.Y. \& London.

LEVAN, A., AND LOTFY, T. 1950. Spontaneous chromosome fragmentation in seedlings of Vicia faba. Hereditas, $36,470-482$.

MAHER, E. P., AND FOX, D. P. 1973. Multiplicity of ribosomal RNA genes in Vicia species with different nuclear DNA contents. Nature (New Biol.), 245, 170-172.

MICHAElis, A., AND RIEGER, R. 1958. Cytologische und Stoffwechselphysiologishe untersuchtung am aktiven meristem der Wurzelspitze von Vicia faba L. II. Präferentielle verteilung der chromosomalen bruch und Renionspunkte nach anaerober quellung der Saman. Chromosoma (Berl.), 9, 514-536.

мгттшосн, U. 1969. Scope and limitations of Feulgen microdensitometry. Chromosomes Today, II, 90-98. Oliver \& Boyd, Edinburgh.

NARAYAN, R. K. J., AND REES, H. 1974. Nuclear DNA, heterochromatin and phylogeny of Nicotiana amphidiploids. Chromosoma (Berl.), 47, 75-83.

NISHIKAWA, K. 1970. DNA content of the individual chromosomes and genomes in wheat and its relatives. Seiken Ziho, 22, 57-65.

PEgIngton, C., AND REES, H. 1970. Chromosome weights and measures in the Triticinae. Heredity (Lond.), 25, 195-205.

PIERCE, W. P. 1937. The effect of phosphorus on chromosome and nuclear volume in a violet species. Bull. Torrey Bot. Club, 64, 345-354.

southern, D. I. 1967. Species relationships in the genus Tulipa. Chromosoma (Berl.), 23, 80-94.

swifT, H. 1950. The constancy of desoxyribose nucleic acids in plant nuclei. Proc. Nat. Acad. Sci. USA., 36, 643-654.

VENDRELy, R. 1955. The deoxyribonucleic acid content of the nucleus. In Nucleic Acids, II, pp. 155-176, Eds. Chargaff, E. \& Davidson, J. N. Academic Press, N.Y.

VERMA, s. C., AND REES, H. 1974. Nuclear DNA and the evolution of allotetraploid Brassicae. Heredity, 33, 61-68.

YANG, D. P., AND DODSON, E. O. 1970. The amounts of nuclear DNA and the duration of DNA synthesis period $(\mathrm{S})$ in relation to diploid and autotetraploid species of oats. Chromosoma (Berl.), 31, 309-320. 